\title{
Klasifikasi Topik Multi Label pada Hadis Shahih Bukhari Menggunakan K-Nearest Neighbor dan Latent Semantic Analysis
}

\author{
Dian Chusnul Hidayati, Said Al Faraby, Adiwijaya \\ School of Computing, Telkom University, Bandung, Indonesia \\ Email: ${ }^{1}$ dianchusnulh@student.telkomuniversity.ac.id, ${ }^{2}$ saidalfaraby@ telkomuniversity.ac.id, ${ }^{3}$ adiwijaya@ telkomuniversity.ac.id
}

Submitted 20-12-2019; Accepted 03-02-2020; Published 15-02-2020

\begin{abstract}
Abstrak
Hadis merupakan sumber hukum Islam kedua setelah Al-Quran sehingga menjadikan hadis penting untuk dipelajari. Namun dalam mempelajari hadis, terdapat kesulitan untuk menentukan hadis apa saja yang tergolong ke dalam topik anjuran, larangan, dan informasi. Hal ini tentu menjadi kendala, khususnya bagi umat Islam, dalam mempelajari hadis . Oleh karena itu, perlu dilakukannya klasifikasi hadis ke dalam topik anjuran, larangan, dan informasi, atau gabungan dari ketiganya yang disebut sebagai klasifikasi topik multi label. Klasifikasi dapat dilakukan dengan metode K-Nearest Neighbor yang merupakan salah satu metode terbaik dalam Vector Space Model dan merupakan metode paling sederhana namun cukup efektif. Namun KNN memiliki kekurangan dalam menghadapi dimensi vektor yang tinggi, sehingga menyebabkan waktu komputasi klasifikasi yang tinggi pula. Hal ini mendasari dilakukannya klasifikasi Hadis Shahih Bukhari ke dalam topik anjuran, larangan, dan informasi menggunakan metode Latent Semantic Analysis - K-Nearest Neighbor (LSA-KNN) dalam mengatasi kekurangan KNN. Penggunaan metode Binary Relevance juga dilakukan pada penelitian ini untuk memproses multi label data. Penelitian ini menghasilkan performansi LSA-KNN sebesar $90.28 \%$ dengan waktu komputasi sebesar 19 menit 21 detik dan performansi KNN sebesar 90.23\% dengan waktu komputasi sebesar 37 menit 06 detik, sehingga menunjukkan bahwa metode LSA-KNN memiliki kinerja yang lebih baik dibandingkan dengan KNN.
\end{abstract}

Kata Kunci: Hadis, Klasifikasi, Latent Semantic Analysis, K-Nearest Neighbor, Binary Relevance

\begin{abstract}
Hadith is the second source of Islamic law after Al-Quran, making it important to study. However, there are some difficulties in learning hadith, such as to determine which hadith belongs to the topic of suggestions, prohibitions, and information. This certainly obstructs the hadith learning process, especially for Muslims. Therefore, it is necessary to classify hadiths into the topic of suggestions, prohibitions, information, and a combination of the three topics which also called as multi-label topic. The classification can be done with the KNearest Neighbor, it is one of the best methods in the Vector Space Model and is the simplest but quite effective method. How ever, the $\mathrm{KNN}$ has a lack in dealing with high vector dimension, resulting in the long time computing classification. For that reason, it is necessary to classify Sahih Bukhari's Hadiths into the topic of recommendations, prohibitions, and information using the LatentSemantic Analysis - K-nearest Neighbor (LSA-KNN) method. Binary Relevance method is also employed in this research to process the multi-label data. This research shows that the performance of LSA-KNN is $90.28 \%$ with the computation time is 19 minutes 21 seconds and the performance of $\mathrm{KNN}$ is $90.23 \%$ with the computation time is 37 minutes 06 seconds, which means that the LSA-KNN method has a better performance than KNN.
\end{abstract}

Keywords: Hadith, Classification, Latent Semantic Analysis, K-Nearest Neighbor, Binary Relevance

\section{PENDAHULUAN}

Hadis merupakan segala perkataan, perbuatan, ketetapan, dan persetujuan dari Nabi Muhammad SAW [1]. Hal ini menjadikan hadis sebagai pedoman atau sumber hukum kedua umat Islam setelah Al-Qur'an. Segala perkataan, perbuatan, ketetapan, dan persetujuan dari Nabi Muhammad SAW ini kemudian dikumpulkan oleh para ahli hadis. Salah satu di antaranya ialah Imam Bukhari dengan hasilnya yang disebut sebagai Hadis Shahih Bukhari [2].

Berbagai macam ilmu yang dapat dipelajari di dalam hadis menjadikan hadis sebagai sesuatu yang sangat penting untuk dipelajari. Hadis menjelaskan mengenai anjuran untuk melakukan sesuatu, larangan untuk tidak melakukan sesuatu, dan informasi lainnya yang sangat penting untuk dipelajari. Namun dalam mempelajari hadis, terdapat kesulitan dalam menentukan hadis apa saja yang tergolong ke dalam anjuran, larangan, dan informasi, ataupun gabungan di antara ketiganya. Hal ini tentu menjadi kendala, khususnya bagi umat Islam, untuk dapat mempelajari hadis dan maknanya dengan baik. Oleh karena itu, perlu dilakukannya klasifikasi teks Hadis Shahih Bukhari ke dalam anjuran, larangan, dan informasi, ataupun gabungan di antara ketiganya.

Klasifikasi merupakan metode yang dapat mengkategorikan data atau teks ke dalam satu atau lebih kategori. Terdapat beberapa penelitian terdahulu mengenai klasifikasi Hadis Shahih Bukhari terjemahan Indonesia yang menghasilkan performansi yang cukup baik. Penelitian pertama [3] melakukan klasifikasi data single label dengan menggunakan Support Vector Machine dan menghasilkan F1-Score sebear 88\%. Penelitian kedua [4] melakukan klasifikasi data single label dan data multi label dengan menggunakan Information Gain Backpropogation Neural Network. Peelitian ini menghasilkan F1-Score sebesar $65.275 \%$ pada single label dan $88.42 \%$ pada multi label data. Penelitian ketiga [5] melakukan klasifikasi hadis multi label dengan menggunakan Rule-based pada ekstraksi fitur untuk mengurangi dimensional yang tinggi dan menghasilkan Hamming Loss sebesar 0.0623 .

Pada penelitian [6], [7], dan [8], belum dilakukan penelitian terhadap data hadis dengan menggunakan salah satu metode klasifikasi paling sederhana, namun cukup efektif dalam melakukan klasifikasi teks, yaitu metode $k$-Nearest Neighbor (kNN) [9]. KNN merupakan salah satu metode klasifikasi terbaik di dalam Vector Space Model (VSM). Metode KNN merupakan teknik klasifikasi non-parametrik yang sangat efektif berdasarkan pada pengenalan pola statistik. Hal ini 
membuat kNN dapat menghasilkan tingkat akurasi tinggi. Namun dalam klasifikasi teks, KNN juga memiliki beberapa kekurangan, yaitu dalam menghadapi data dengan dimensi vektor yang tinggi yang menyebabkan ruang yang besar dan waktu komputasi yang tinggi. [10]. Oleh karena itu, diperlukan metode yang lebih efektif untuk dapat mereduksi dimensi agar mengurangi waktu komputasi dari algoritma KNN [10].

Penelitian [10] melakukan klasifikasi teks dengan menggunakan improvisasi terhadap algoritma KNN menggunakan Latent Semantic Analysis (LSA). LSA mampu mereduksi fitur vector, sehingga mampu mengurangi kompleksitas waktu klasifikasi KNN. Penelitian [10] juga membuktikan bahwa performansi yang didapat pada LSA KNN mengalami peningkatan jika dibandingkan dengan klasifikasi menggunakan KNN saja.

Penelitian ini akan melakukan melakukan klasifikasi data hadis Shahih Bukhari ke dalam anjuran, larangan, informasi, atau gabungan di antara ketiganya yang disebut sebagai klasifikasi teks topik multi label. Penelitian ini menggunakan LSA - KNN sebagai metode klasifikasinya. Namun, klasifikasi teks dengan menggunakan LSA - KNN pada dasarnya hanya dapat melakukan klasifikasi teks terhadap single label data. Dengan demikian, penelitian ini juga akan menggunakan Binary Relevance (BR) untuk dapat mentransformasikan data multi label menjadi single label [11].

\section{METODE PENELITIAN}

Penelitian ini membangun sistem yang dapat melakukan klasifikasi multi label topik terhadap data Hadis Shahih Bukhari terjemahan Bahasa Indonesia menggunakan algoritma K-Nearest Neighbor dan Latent Semantic Analysis. Terdapat beberapa tahapan yang dilakukan dalam membangun sistem ini, yaitu preprocessing, ekstraksi fitur menggunakan TF-IDF dan rule-based, reduksi dimensi menggunakan LSA, transformasi multi label menjadi single label menggunakan BR, klasifikasi menggunakan KNN, dan evaluasi menggunakan perhitungan F1-Score. Gambaran sistem secara umum dapat dilihat pada Gambar 1.

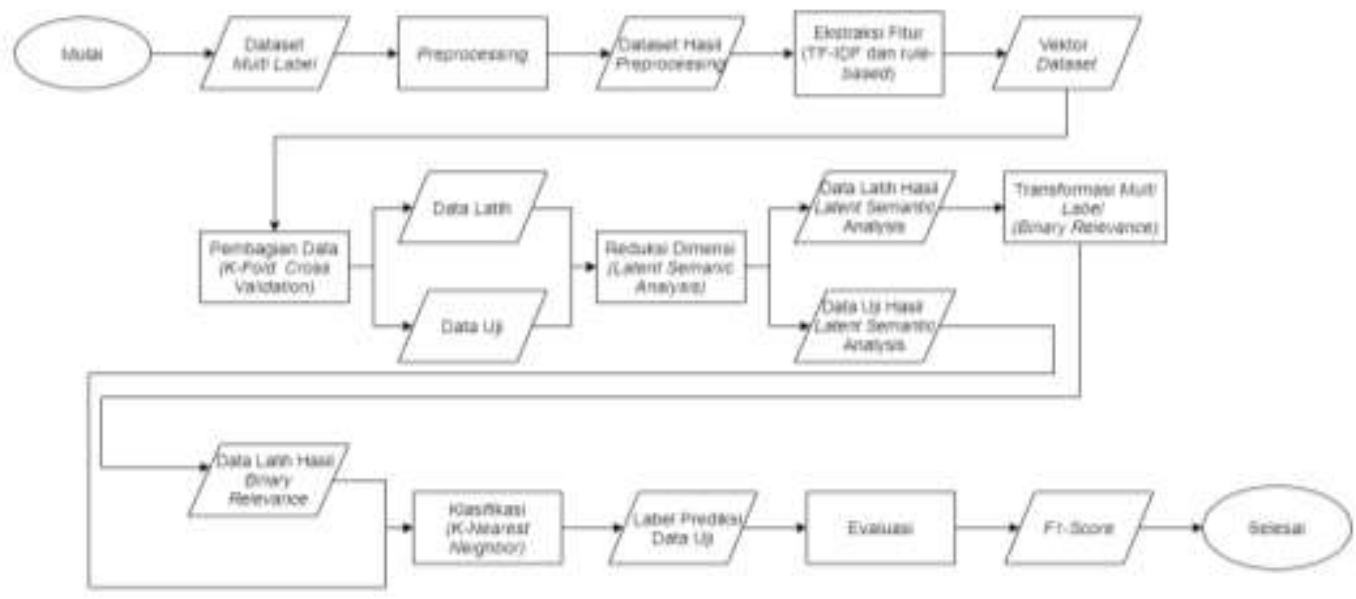

Gambar 1. Diagram Alur Sistem

\subsection{Data Set}

Penelitian ini menggunakan 2000 data Hadis Shahih Bukhari terjemahan Bahasa Indonesia. Data tersebut sebelumnya telah diberi label secara manual atau hand-labelling oleh penelitian [4] sesuai dengan karakteristik dari setiap topik, kemudain dilakukan validasi pada sampel data oleh pihak yang expert di bidangnya. Data hadis ini bersifat multi label yang terdiri dari tiga kelas yaitu anjuran, larangan dan informasi. Jumlah data dengan label 1 pada kelas anjuran, larangan, dan informasi ialah sebesar 376, 204, dan 1977. Contoh data hadis yang digunakan pada penelitian ini dapat dilihat pada Tabel 1.

Tabel 1. Representasi Data

\begin{tabular}{lccc}
\hline \multicolumn{1}{c}{ Hadis } & Anjuran & Laranngan & Informasi \\
\hline $\begin{array}{l}\text { Janganlah kamu pindah atau pergi hingga kamu mendengar } \\
\text { suara atau mencium baunya. [4] }\end{array}$ & 0 & 1 & 1 \\
\hline
\end{tabular}

\subsection{Preprocessing}

Preprocessing membersihkan dataset dari unsur-unsur yang tidak diperlukan selama proses klasifikasi. Gambaran proses preprocessing yang dilakukan ialah seperti pada Gambar 2 berikut: 


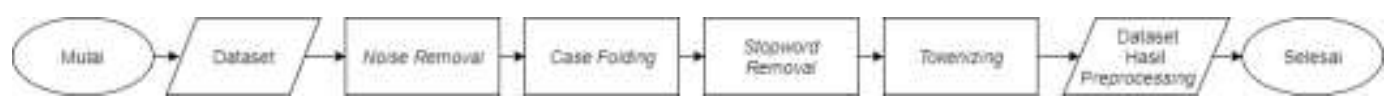

Gambar 2. Tahapan Preprocessing

Proses preprocessing seperti yang telah digambarkan pada Gambar 3 ialah sebagai berikut:

a. Noise Removal, menghilangkan noise yang berupa tanda baca, angka, dan karakter non-ASCII.

b. Case Folding, mengubah seluruh huruf kapital menjadi huruf kecil atau sebaliknya.

c. Stopword Removal, menghilangkan kata-kata yang dianggap memiliki pengaruh yang kecil, yang merupaan kata dengan frekuensi kemunculan yang tinggi dibandingkan dengan kata-kata lainnya.

d. Tokenizing, memecah kalimat dari setiap dokumen pada dataset yang sudah bersih ke dalam kata perkata.

\subsection{Ekstraksi Fitur}

Ekstraksi Fitur yang digunakan ialah dengan penggabungan metode TF-IDF dan rule-based. Perhitungan TF-IDF dengan penambahan rule-based sebagai fiturnya. TF-IDF merupakan metode statistik yang digunakan untuk menilai tingkat kepentingan suatu kata terhadap suatu dokumen atau kategori dalam kumpulan file untuk menentukan karakteristik dokumen menggunakan kata-kata dengan tingkat kepentingan yang tinggi. TF-IDF terdiri dari dua bagian, yaitu Term Frequency (TF) dan Invers Document Frequency (IDF). TF adalah merupakan jumlah kemunculan setiap kata pada setiap dokumen dan IDF merepresentasikan jumlah dokumen yang memiliki kata tertentu berdasarkan jumlah kata dalam teks. Perhitungan TF-IDF dapat dilakukan dengan menggunakan rumus seperti pada persamaan 1 [12].

$$
W_{i, j}=t f_{i, j} \times i d f=t f_{i j} \times \log \left(\frac{D}{d f_{i}}\right)
$$

Keterangan :

$\mathrm{w}_{\mathrm{ij}}=$ Bobot kata $\mathrm{t}_{\mathrm{j}}$ terhadap dokumen $\mathrm{d}_{\mathrm{i}}$

$\mathrm{tf}_{\mathrm{ij}}=$ Jumlah kemunculan kata $\mathrm{t}_{\mathrm{j}}$ dalam dokumen $\mathrm{d}_{\mathrm{i}}$

$\mathrm{D}=$ Jumlah dokumen

$\mathrm{Df}_{\mathrm{i}}=$ Jumlah kemunculan kata dalam dokumen

Rule-Based digunakan sebagai metode pemilihan fitur yang dapat meningkatkan efisiensi dari sistem yang dibangun [5]. Rule-based dibangun dengan cara mengamati pola kalimat dari kata dan susunan kata dari banyak data Hadis sebagai representasi dari seluruh hadis berdasarkan penelitian [5]. Aturan-aturan yang dimiliki untuk mendefinisikan label anjuran terdapat pada Tabel 2 [5].

Tabel 2. Aturan Topik Anjuran

\begin{tabular}{ll}
\hline \multicolumn{1}{c}{ Aturan } & \multicolumn{1}{c}{ Contoh Kata } \\
\hline Kata dengan kelas kata (VB) + lah & $\underline{\text { Makanlah }}$ \\
Kata dengan kelas kata (RB) + lah & $\underline{\text { Segeralah }}$ \\
Kata dengan kelas kata (JJ) + lah & $\underline{\text { Beramallah }}$ \\
Kata yang mengandung 'anjur' dan memiliki kelas kata (VB) & Menganjurkan \\
Kata yang mengandung 'wajib' dan memiliki kelas kata (VB) & Mewajibkan \\
Kata 'kewajiban' dan memiliki kelas kata (NN) & Kewajiban \\
Kata Hendaknya / Hendak & Hendaknya / Hendak \\
Kata Mentaati / Mentaatiku & Mentaati / Mentaatiku \\
Kata Sebaik-baiknya & Sebaik-baiknya \\
\hline
\end{tabular}

topik larangan terdapat pada Tabel 3 [5],

Tabel 3. Aturan Topik Larangan

\begin{tabular}{ll}
\hline \multicolumn{1}{c}{ Aturan } & \multicolumn{1}{c}{ Contoh Kata } \\
\hline Kata dengan kelas kata (NEG) + lah & $\underline{\text { Janganlah }}$ \\
Kata yang mengandung 'larang' & Melarang \\
Kata yang mengandung 'haram' & Diharamkan \\
Urutan kata 'tidak pernah' dan setelahnya adalah kata dengan & tidak pernah dihalalkan \\
kelas kata (VB) & Tidak menyekutukannya \\
Urutan kata 'tidak menyekutukannya' & Jangan \\
Kata Jangan & Membangkang \\
Kata Membangkang & Mendurhakaiku \\
Kata Mendurhakaiku & \\
\hline
\end{tabular}


dan topik larangan terdapat pada Tabel 4 [5].

Tabel 4. Aturan Topik Informasi

\begin{tabular}{ll}
\hline \multicolumn{1}{c}{ Aturan } & Contoh Kata \\
\hline Kata yang diawali dengan 'me-' dan diakhiri dengan '-kan' dan & Mempekerjakan \\
kata tersebut memiliki kelas kata (VB) & Niscaya \\
Niscaya & Sesungguhnya \\
Sesungguhnya & Bahwa \\
Bahwa & Apabila \\
Apabila & Maka \\
Maka & Barangsiapa \\
Barangsiapa & \\
\hline
\end{tabular}

\subsection{Reduksi Dimensi}

Latent Semantic Analysis merupakan metode unsupervised yang berdasarkan pada teori komputasi atau perhitungan statistika untuk mengekstrak dan merepresentasikan makna konseptual dari fitur-fitur dan kesamaan dokumen menjadi representasi vector, dimana ide utamanya adalah kata-kata yang digunakan dalam konsep yang sama cenderung memiliki makna yang sama [10]. LSA didasarkan pada teknik matematika yang diberi nama Singular Value Decomposition (SVD) [13].

Singular Value Decomposition (SVD) adalah teknik matematika matriks dekomposisi untuk mengidentifikasi pola dalam hubungan antara fitur dan dokumen yang terdapat dalam koleksi terstruktur teks dan menentukan kesamaan makna fitur dan dokumen. SVD didasarkan pada teorema dari aljabar linier dimana matriks segi empat A dari representasi vektor term-document data latih asli didekomposisi menjadi 3 matriks, yaitu matriks orthogonal U, matriks diagonal $\Sigma$, dan transpose matriks orthogonal $\mathrm{V}^{\mathrm{t}}$ [14]. Gambaran dari dekomposisi matriks menggunakan SVD terlihat pada Gambar 2.
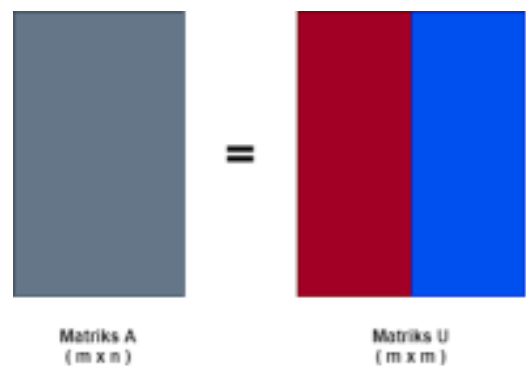

Gambar 3. Singular Value Decomposition

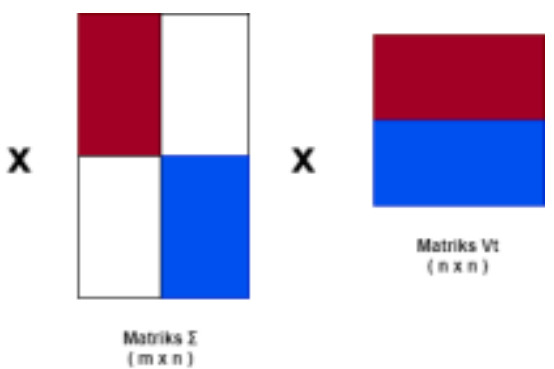

Matriks U merupakan matriks yang kolomnya adalah eigen vectors dari matriks $\mathrm{AA}^{\mathrm{t}}$. Matriks ini juga disebut eigen vector kiri dan merepresentasikan hubungan antara fitur dengan konsep. Kemudian, matriks $\Sigma$ merupakan matriks yang nilai diagonalnya adalah nilai singular dari matriks A. Matriks ini merepresentasikan hubungan antar konsep. Matriks terakhir, yaitu matriks $\mathrm{V}^{\mathrm{t}}$ merupakan matriks transose dari matriks $\mathrm{V}$, dimana matriks $\mathrm{V}$ merupakan matriks yang kolomnya adalah eigen vectors dari matriks $\mathrm{A}^{\mathrm{t}} \mathrm{A}$. Matriks $\mathrm{V}^{\mathrm{t}}$ ini disebut eigen vector kanan dan merepresentasikan hubungan antara konsep dengan dokumen.

Setelah didapatkan dekomposisi dari vektor dokumen data latih asli menjadi matriks $\mathrm{U}, \Sigma$, dan $\mathrm{V}^{\mathrm{t}}$, maka selanjutnya dilakukan reduksi dimensi vektor. Reduksi dimensi vektor dilakukan dengan mengambil sejumlah k dimensi fitur yang digunakan. Sehingga matriks yang dimiliki menjadi $\mathrm{U}_{\mathrm{k}}(\mathrm{m} \mathrm{x} \mathrm{k}), \Sigma_{\mathrm{k}}(\mathrm{k} \mathrm{x} \mathrm{k})$, dan $\mathrm{V}_{\mathrm{k}}(\mathrm{k} \mathrm{x} \mathrm{n})[10]$.

Penggunaan Latent Semantic Analysis pada klasifikasi teks ini menghasilkan matriks baru yang mampu mengurangi dimensi menjadi sejumlah $\mathrm{k}$ dimensi. Matriks representasi dokumen pada data uji dan data latih yang baru diperoleh menggunakan persamaan 2 [14] sebagai berikut:

Keterangan :

$$
\mathrm{d}^{*}=\mathrm{d}^{\mathrm{T}} \mathrm{U}_{\mathrm{k}}
$$

$$
\begin{aligned}
& \mathrm{d}^{*}=\text { Vektor dokumen baru hasil reduksi dimensi } \\
& \mathrm{d}^{\mathrm{T}}=\text { Vektor dokumen asli } \\
& \mathrm{U}_{\mathrm{k}}=\text { Eigen vector kiri hasil SVD }
\end{aligned}
$$

\subsection{Transformasi Multi Label}

Transformasi multi label pada penelitian ini menggunakan Binary Relevance. Binary Relevance (BR) merupakan metode yang paling sederhana dan paling populer untuk dapat mentransformasikan permasalahan multi label data menjadi sejumlah permasalahan single label. [15]. BR melakukan transoformasi data tanpa mempertimbangkan ketergantungan antar label [15]. 
Representasi data setelah dilakukan Binary Relevance diperlihatkan pada Tabel 4 untuk topik anjuran,

Tabel 5. Representasi Hasil Binary Relevance Topik Anjuran

\begin{tabular}{cc}
\hline Hadis & Anjuran \\
\hline Janganlah kamu pindah atau pergi hingga kamu mendengar suara atau mencium baunya. [4] & 0 \\
\hline
\end{tabular}

Tabel 6 untuk topik larangan.

Tabel 6. Representasi Hasil Binary Relevance Topik Larangan

\begin{tabular}{cc}
\hline Hadis & Larangan \\
\hline Janganlah kamu pindah atau pergi hingga kamu mendengar suara atau mencium baunya. [4] & 1
\end{tabular}
dan Tabel 8 untuk topik informasi.

Tabel 7. Representasi Hasil Binary Relevance Topik Informasi

\begin{tabular}{cc}
\hline Hadis & Informasi \\
\hline Janganlah kamu pindah atau pergi hingga kamu mendengar suara atau mencium baunya. [4] & 1 \\
\hline
\end{tabular}

\subsection{Klasifikasi}

Klasifikasi dilakukan dengan menggunakan metode $K$-Nearest Neighbor (KNN). KNN adalah pembelajaran algoritma klasifikasi supervised. Secara umum, algoritma KNN dapat dilihat dilakukan dengan tahapan sebagai berikut [10]:

1) Tentukan nilai $K$

2) Ulangi untuk setiap data dalam data uji, lakukan:

i) Hitung nilai kemiripan data uji terhadap seluruh data latih menggunakan Cosine Similarity dengan persamaan 3.

ii) Urutkan nilai kemiripan secara descending

iii) Pilih objek pada data latih sejumlah k tetangga terdekat terhadap objek data uji

iv) Pilih kelas terbanyak yang dimiliki oleh $\mathrm{k}$ tetangga terdekat

\section{ANALISA DAN PEMBAHASAN}

Pengujian sistem dilakukan dengan membagi data uji dan data latih menggunakan 5-Fold Cross Validation yang membagi 2000 data hadis menjadi 1600 data latih dan 400 data uji. Dataset yang telah dibagi kemudian digunakan dalam pengujian klasifikasi LSA-KNN. Pengujian dilakukan untuk mendapatkan hasil performansi sistem yang terbaik.

Pada skenario 1 pengujian sistem dilakukan pengujian terhadap formula pembentukan data uji dan data latih hasil LSA. Skenario ini menggunakan 13-nearest neighbor dan persentasi dimensi vektor sebesar 30\% pada LSA sebagai parameternya. Kemudian dilakukan pengujian terhadap penggunaan formula $d^{*}=d^{T} U_{k} \Sigma_{k}^{-1} d a n d^{*}=d^{T} U_{k}$ sebagai parameter yang akan diuji. Skenario ini dilakukan untuk mengetahui pengaruh formula pembentukan data uji dan data latih hasil LSA terhadap performansi sistem. Hasil performansi dari skenario 1 tertera pada Tabel 8.

Tabel 8. Hasil Pengujian Skenario 1

\begin{tabular}{lc}
\hline \multicolumn{1}{c}{ Formula } & $F$-1 Score \\
\hline $\mathrm{d}^{*}=\mathrm{d}^{\mathrm{T}} \mathrm{U}_{\mathrm{k}} \Sigma_{\mathrm{k}}^{-}$ & 86.88 \\
$\mathrm{~d}^{*}=\mathrm{d}^{\mathrm{T}} \mathrm{U}_{\mathrm{k}}$ & $\mathbf{8 8 . 5 4}$ \\
\hline
\end{tabular}

Hasil yang didapat dan ditampilkan pada Tabel 8 menunjukkan performansi terbaik terdapat pada penggunaan formula $\mathrm{d}^{*}=\mathrm{d}^{\mathrm{T}} \mathrm{U}_{\mathrm{k}}$. Pada formula ini tidak digunakan matriks $\Sigma_{\mathrm{k}}{ }^{-1}$ sebagai matriks pengali, dimana matriks ini merupakan singular value yang terurut secara descending dan melambangkan makna konseptual yang tersembunyi (latent semantic) dari matriks term-document asli. Matriks ini tentu akan memiliki keterhubungan yang kuat, tidak hanya dengan term yang ada, namun juga dengan documentnya. Oleh karena itu, penggunaan matriks ini akan menurunkan performansi sistem yang juga melibatkan nilai makna konseptual terhadap document. Hal ini menyebabkan pembangunan sistem tanpa perkalian matriks $\Sigma_{\mathrm{k}}{ }^{-1}$ dalam membangun data latih dan data uji baru menghasilkan performansi yang lebih baik, karena hanya menggunakan matriks dokumen asli $\left(\mathrm{d}^{\mathrm{T}}\right)$ dan matriks yang merepresentasikan keterhubungan antara term dengan makna konseptual term yang tersembunyi $\left(\mathrm{U}_{\mathrm{k}}\right)$.

Setelah ditentukannya formula yang terbaik, maka dilakukan skenario 2 pengujian sistem. Pada skenario 2 dilakukan pengujian terhadap persentasi jumlah dimensi vektor yang akan digunakan. Skenario ini menggunakan 13nearest neighbor dalam klasifikasinya. Kemudian dilakukan pengujian terhadap persentasi dimensi vektor sebesar 30 , 
20, 10, 5, dan 2,2 sebagai parameternya. Skenario ini dilakukan untuk mencari persentase jumlah dimensi vektor terbaik yang dalam melakukan klasifikasi dengan metode LSA-KNN. Hasil performansi yang didapat dari skenario pengujian dapat dilihat pada Tabel 9.

Tabel 9. Hasil Pengujian Skenario 2

\begin{tabular}{rrrrr}
\hline \multirow{2}{*}{$\begin{array}{c}\text { \% Dimensi } \\
\text { Vektor }\end{array}$} & \multirow{2}{*}{$\begin{array}{c}\text { Jumlah Dimensi } \\
\text { Vektor }\end{array}$} & Precision $(\%)$ & Recall $(\%)$ & F1-Score $(\%)$ \\
\cline { 3 - 5 } 30 & 1600 & 96.30 & 81.97 & 88.54 \\
20 & 1388 & 96.34 & 82.00 & 88.58 \\
10 & 694 & 96.23 & 82.37 & $\mathbf{8 8 . 7 4}$ \\
5 & 347 & 94.84 & 82.92 & 88.45 \\
2.2 & 150 & 93.58 & 83.01 & 87.99 \\
\hline
\end{tabular}

Dari hasil pengujian pada skenario 2, hal yang dapat dianalisis dari Tabel 9 ialah hasil performansi sistem terbaik didapatkan dengan penggunaan persentasi dimensi vektor sebesar 10\% dengan jumlah fitur sebesar 694 . Hal ini menunjukkan bahwa semakin tinggi dimensi fitur yang digunakan, maka hasil performansi sistem akan membaik, namun jika sudah melebihi titik optimum, maka performansi sistem akan menurun. Performansi yang menurun ini disebabkan oleh semakin bertambahnya fitur-fitur yang tidak dibutuhkan oleh sistem karena memiliki korelasi atau nilai makna konseptual yang rendah terhadap dokumen yang dimiliki. Pada titik optimum, yaitu dengan jumlah dimensi sebesar $10 \%$ dari data asli, ruang semantik yang baru sudah mampu mewakili ruang fitur yang sebenarnya.

Skenario selanjutnya, yaitu skenario 3, melakukan pengujian sistem terhadap penggunaan stemming dalam tahapan preprocessing untuk metode LSA-KNN. Pengujian ini dilakukan untuk mengetahui pengaruh penggunaan stemming dalam pembangunan sistem terhadap data Hadis Shahih Bukhari. Hasil performansi yang didapat dari skenario pengujian terdapat pada Tabel 10 .

Tabel 10. Hasil Pengujian Skenario 3

\begin{tabular}{lrrr}
\hline Stemming & \multicolumn{3}{c}{ Performansi } \\
\cline { 2 - 4 } & Precision (\%) & Recall (\%) & F1-Score (\%) \\
\hline Ya & 94.46 & 82.28 & 87.94 \\
Tidak & 96.23 & 82.37 & $\mathbf{8 8 . 7 4}$
\end{tabular}

Tabel 10 memperlihatkan bahwa penggunaan stemming pada data Hadis Shahih Bukhari dengan metode LSAKNN tidak memberikan performansi sistem yang lebih baik. Hal tersebut terjadi karena data hadis setelah preprocessing dengan melakukan stemming dapat menghapus karakteristik dari setiap topik atau kelas.

Berdasarkan pengujian skenario 3, maka dilakukan pengujian untuk mencoba meningkatkan performansi sistem pada setiap topiknya. Pengujian yang dilakukan adalah dengan menambahkan rule-based feature extraction pada metode TF-IDF. Hasil pengujian TF-IDF dan rule-based dapat dilihat pada Tabel 11.

Tabel 11. Hasil Pengujian Skenario 4

\begin{tabular}{lrr}
\hline \multirow{2}{*}{ Topik } & \multicolumn{2}{c}{ Fl-Sore (\%) } \\
\cline { 2 - 3 } & TF-IDF & TF-IDF dan Rule-Based \\
\hline Anjuran & 27.81 & 36.40 \\
Larangan & 40.66 & 58.83 \\
Informasi & 99.42 & 99.42 \\
Keseluruhan & 88.74 & $\mathbf{9 0 . 2 8}$ \\
Topik & & \\
\hline
\end{tabular}

Berdasarkan hasil yang diperoleh pada skenario 4 dengan hasil seperti pada tabel 11, dapat dibuktikan bahwa penggunaan Rule-Based sebagai ekstraksi fitur mampu meningkatkan performansi sistem. Hal ini disebabkan oleh pendefinisian yang lebih nyata berdasarkan aturan yang dimiliki untuk membedakan karakteristik setiap topik. Contoh perbedaan hasil klasifikasi menggunakan TF-IDF dan penggabungan antara TF-IDF dan Rule-Based terdapat pada Tabel 12.

Tabel 12. Data Hasil Pengujian Skenario 4

\begin{tabular}{|c|c|c|c|}
\hline \multirow[t]{2}{*}{ Hadis } & Target & \multicolumn{2}{|c|}{ Prediksi } \\
\hline & & TF-IDF & $\begin{array}{l}\text { TF-IDF dan } \\
\text { Rule-Based }\end{array}$ \\
\hline
\end{tabular}




\begin{abstract}
Janganlah kamu pergi hingga engkau mendengar
suara atau mencium bau. [4]

Jika salah seorang dari kalian masuk ke dalam

WC untuk buang hajat, maka janganlah menghadap ke arah kiblat membelakanginya.

Hendaklah ia menghadap ke arah timurnya atau baratnya. [4]

Sebab itu hanyalah semisal keringat dan bukan darah haid. Jika datang haidmu maka tinggalkan shalat, dan jika telah terhenti maka bersihkanlah sisa darahnya lalu shalat. Hisyam berkata, Bapakku (Urwah) menyebutkan, Berwudlulah kamu setiap akan shalat hingga waktu itu tiba. [4]
\end{abstract}

$0,1,1$

$0,0,1$

$0,1,1$

$1,1,0$

$0,1,1$

$1,1,1$

$1,1,1 \quad 0,0,1 \quad 1,0,1$

Pada Tabel 12 ini, penggunaan rule-based pada hadis pertama mampu mengenali kata "Janganlah" sebagai suatu bentuk karakteristik dari topik larangan pada data pertama, mendefinisikan kata "Hendaklah" sebagai anjuran pada data kedua, dan "bersihkanlah" pada sebagai anjuran pada data ketiga, sedangkan TF-IDF tanpa menggunakan rule-based belum mampu mengenali karakteristik tersebut. Namun kedua percobaan ini masih belum bisa membedakan data mana yang termasuk ke dalam informasi, seperti yang terjadi pada data kedua. Hal ini dapat terjadi karena perbedaan suatu hadis termasuk ke dalam informasi juga sulit dibedakan secara kasar mata, selain itu data latih yang dimiliki terdiri dari 1977 untuk kelas 1 dan 44 untuk kelas 0 pada topik informasi. Sehingga rule mengenai dokumen mana yang termasuk informasi itu membuat sistem tetap mengenal dokumen mana yang termasuk informasi, namun sistem masih kesulitan menentukan dokumen mana yang tidak termasuk ke dalam informasi karena kurangnya bahan pembelajaran yang dimilikinya. Pada data ketiga juga terlihat juga bahwa penggunaan TF-IDF saja ataupun gabungan antara TF-IDF dan rule-based belum benar-benar mampu mengenali larangan yang memiliki makna implisit dari suatu susunan kata.

Setelah melakukan pengujian untuk memaksimalkan metode dan parameter yang digunakan pada algoritma LSA-KNN, maka selanjutnya dilakukan perbandingan hasil dari penggunaan metode LSA-KNN dan KNN. Hasil pengujian ini terdapat pada Tabel 13.

Tabel 13. Hasil Pengujian Skenario 5

\begin{tabular}{lcr}
\hline \multirow{2}{*}{ Metode } & \multicolumn{2}{c}{ Parameter Pengujian } \\
\cline { 2 - 3 } & Waktu perFold & F1-Score (\%) \\
\hline KNN & 37 menit 06 detik & 90.23 \\
LSA-KNN & 19 menit 21 detik & 90.28 \\
\hline
\end{tabular}

Hasil yang terdapat pada Tabel 13 membuktikan bahwa metode LSA-KNN mampu meningkatkan kinerja sistem jika dibandingkan dengan metode KNN. Penggunaan LSA pada metode KNN mampu meningkatkan performansi dan menurunkan waktu komputasi. Hal ini disebabkan oleh penggunaan metode LSA yang mampu menganalisis hubungan atara term dan document sehingga mampu menemukan makna tersembunyi di dalam dataset. Penggunaan LSA juga mampu mengurutkan tingkat keterhubungan makna kontekstual secara tersembunyi, sehinga mampu memunculkan representasi jumlah dimensi ruang semantik yang lebih rendah dari aslinya dengan mengambil sejumlah $\mathrm{k}$ dimensi terpenting. Berkurangnya dimensi fitur yang digunakan pada proses klasifikasi inilah yang menjadi penyebab berkurangnya waktu komputasi

\title{
4. KESIMPULAN
}

Berdasarkan hasil pengujian dan analisis yang telah dilakukan, maka dapat disimpulkan bahwa beberapa rangkaian metode, perhitungan, atau parameter yang lebih baik digunakan pada LSA-KNN dengan 2000 data Hadis Shahih Bukhari terjemahan Indonesia ialah penggunaan formula $\mathrm{d}^{*}=\mathrm{d}^{\mathrm{T}} \mathrm{U}_{\mathrm{k}}$ untuk membangun data latih dan data uji baru, persentasi dimensi fitur optimal yang digunakan sebesar $10 \%$ dari jumlah fitur sebenarnya, preprocessing tanpa penggunaan stemming, dan penambahan rule-based sebagai fitur pada proses ekstraksi fitur.

Penelitian ini menghasilkan performansi sistem sebesar 90.28\% dengan waktu komputasi sebesar 19 menit 21 detik dan performansi KNN sebesar $90.23 \%$ dengan waktu komputasi sebesar 37 menit 06 detik. Hal ini menunjukkan bahwa penggunaan metode LSA-KNN dalam mengadaptasi metode KNN mampu meningkatkan kinerja sistem, baik dalam menghasilkan performansi ataupun dalam pengurangan waktu komputasi.

Metode yang dibangun pada penelitian ini cocok digunakan pada multi label topik dengan jumlah dokumen dan fitur yang sangat besar, namun kurang maksimal pada data yang bersifat imbalance. Sehingga untuk penelitian selanjutnya, disarankan melakukan penambahan data pada setiap topik dengan data yang lebih seimbang. Jika data yang digunakan bersifat imbalance, gunakan rule-based untuk menentukan karakteristik topik / label pada kelas yang minimum.

\section{REFERENCES}

[1] Jonathan A. C. Brown, Misquoting Muhammad: The Challange and Choices of Interpreting the Prophet's Legacy. 2015. 
JURIKOM (Jurnal Riset Komputer), Vol. 7 No. 1, Februari 2020 e-ISSN 2715-7393 (Media Online), p-ISSN 2407-389X (Media Cetak)

[2] Muhammad Vandestra, Kitab Hadist Shahih Bukhari \& Muslim Edisi Bahasa Indonesia. Dragon Promedia, 2018.

[3] H. Fauzan, S. Al-faraby, and Adiwijaya, "Pengklasifikasian Topik Hadits Terjemahan Bahasa Indonesia Menggunakan Latent Semantic Indexing dan Support Vector Machine,” Media Inform. Budidarma, vol. 2, no. 4, pp. 131-139, 2018.

[4] M. Y. Abu Bakar, Adiwijaya, and S. Al Faraby, "Multi-Label Topic Classification of Hadith of Bukhari (Indonesian Language Translation)Using Information Gain and Backpropagation Neural Network," Proc. 2018 Int. Conf. Asian Lang. Process. IALP 2018, pp. 344-350, 2019.

[5] G. Mediamer, adiwijaya@telkomuniversity ac id Adiwijaya, and S. Al Faraby, "Development of rule-based feature extraction in multi-label text classification,” Int. J. Adv. Sci. Eng. Inf. Technol., vol. 9, no. 4, pp. 1460-1465, 2019.

[6] M. Arshi, S. Norisma, I. Rohana, S. Ja, and T. Abdullah, "Hadith data mining and classification : a comparative analysis," Artif. Intell. Rev., 2016.

[7] S. Al Faraby, E. R. Rachmawati, Y. Irwanto, and M. A. Bijaksana, "Text Categorization on Hadith Sahih Al-Bukhari using Random Forest Text Categorization on Hadith Sahih Al-Bukhari using Random Forest."

[8] Al Faraby, S., Jasin, E.R.R. and Kusumaningrum, A., 2018, March. Classification of hadith into positive suggestion, negative suggestion, and information. In Journal of Physics: Conference Series (Vol. 971, No. 1, p. 012046). IOP Publishing.

[9] Z. Yong, L. Youwen, and X. Shixiong, “An Improved KNN Text Classification Algorithm Based on Clustering,” vol. 4, no. 3, pp. $230-237,2009$.

[10] Sari, P. K., \& Purwadinata, A. (2019). "Analysis Characteristics of Car Sales In E-Commerce Data Using Clustering Model". Journal of Data Science and Its Applications, 2(1), 68-77.

[11] Zhang, M.L., Li, Y.K., Liu, X.Y. and Geng, X., 2018. "Binary relevance for multi-label learning: an overview". Frontiers of Computer Science, 12(2), pp.191-202

[12] I. Yahav, O. Shehory, and D. Schwartz, "Comments Mining With TF-IDF : The Inherent Bias and Its Removal," vol. 14, no. 8, 2018.

[13] Naf'an, M. Z., Bimantara, A. A., Larasati, A., Risondang, E. M., \& Nugraha, N. A. S. (2019). "Sentiment Analysis of Cyberbullying on Instagram User Comments". Journal of Data Science and Its Applications, 2(1), 88-98.

[14] K. Merchant, "NLP Based Latent Semantic Analysis for Legal Text Summarization,” 2018 Int. Conf. Adv. Comput. Commun. Informatics, pp. 1803-1807, 2018.

[15] A. Melo and H. Paulheim, "Local and global feature selection for multilabel classification with binary relevance: An empirical comparison on flat and hierarchical problems," Artif. Intell. Rev., vol. 51, no. 1, pp. 33-60, 2019.

[16] Adiwijaya, Aulia, M.N., Mubarok, M.S., Novia, W.U. and Nhita, F., 2017, May. A comparative study of MFCC-KNN and LPC-KNN for hijaiyyah letters pronounciation classification system. In Information and Communication Technology (ICoIC7), 2017 5th International Conference on (pp. 1-5). IEEE.

[17] Pratiwi, A.I., Adiwijaya, 2018. "On the feature selection and classification based on information gain for document sentiment analysis." Applied Computational Intelligence and Soft Computing, 2018. 